\title{
The Extract Welch Starfruit Leaves Of Water Levels, Proteins And Fats Skipjack (Katsuwonus Pelamis ) Smoke
}

\author{
Ida Astuti ${ }^{* 1}$, Asniati Ningsih ${ }^{2}$ \\ Gorontalo University, Agriculture,Fisheries and Marine, Gorontalo,Indonesia \\ *e-mail: ${ }^{* 1}$ badariadgkanang@gmail.com; ${ }^{2}$ nitaaazis20@gmail.com
}

\begin{abstract}
Some food ingredients are needed by living things because they contain food substances needed in growth. This substance is commonly called the nutrient content of the food. This substance is very important, especially in metabolic processes such as breaking protein into amino acids needed for the growth of babies, children, and also helps maintain the function of carbohydrates as an energy source. The purpose of this study was to determine the effect of extracts on nutrient levels of skipjack (Katsu wonu spelamis) fufu (smoke). This study used a completely randomized design, with two treatments (the use of preservatives and without preservatives) with 3 replications. Based on the results of the study it was found that the extract of the welch starfruit leaves did not significantly affect the protein and fat content but significantly affected the water content.
\end{abstract}

Keywords - extract, welch starfruit leaves, skipjack, smoke, preservatives, and nutrients

\section{INTRODUCTION}

Skipjack (Katsuwonuspelamis) is a type of marine fish commonly consumed by the people of Indonesia and has a high protein content that is good for the human body so skipjack is an important pelagic fishery resource and is one of the non-oil export commodities [1] Skipjack tuna is found in almost all Indonesian waters, especially in the eastern part of Indonesia. Gorontalo Province is one of the regions that have the potential to produce skipjack (Katsuwonuspelamis). In 2009-2010 the production amounted to 7,609 tons [2].

The production of skipjack in North Gorontalo Regency reached 4,979 tons while tuna fish reached 4,086 tons [3]. This is equivalent to Rp. 319 billion from the total production achievement of Rp. 23,563 tons. Whereas according to the Central Gorontalo Regency Central Bureau of Statistics stated that in 2016 the production of catches of skipjack fish reached 4,000 tons. Not all of these skipjack fish are sent to Manado and other districts, but the community has processed them into processed products of economic value, both traditional and modern.

Fishery products are one type of food that needs to be addressed about food security. Given that Indonesia is the largest maritime country in Southeast Asia, the fisheries sector plays an important role in the national

IJoASER,Volume 2,Issue 1,March,2019

DOI: 10.33648/ijoaser.v2i1.22

Copyriht: STAI Al-Furqan Makassar,Indonesia

Content License: CC-BY-SA 
economy. Therefore, proper handling is needed to maintain the export quality of fishery products. One method of preservation that has been done is the use of smoke to inhibit bacteria. But fish that have been preserved with smoked only last fora few days.

Flavonoids are almost found in all parts of the plant including fruit, roots, leaves, and outer bark. Flavonoids are natural compounds that have the potential as antioxidants which can counteract free radicals that play a role in the emergence of degenerative diseases through the mechanism of damage to the body's immune system, lipid oxidation and protein [4].

\section{METHOD}

This research was carried out at the University of Gorontalo and the implementation time was from March to June 2019. The sample analysis was carried out at the Animal Feed Nutrition Laboratory of the University of Hasanuddin Makassar. The resistance of this Research Research Phase is as follows: a. Making Extracts of starfruit leaves used as raw material for extracts are young starfruit leaves. This leaf is obtained from the resident's garden in Kec, LimbotoKab. Gorontalo. Leaves that have been obtained are washed clean and dried using an oven at 500 for 2 days or dried in the sun for 3-4 days. After that, starfruit leaves are mashed and then macerated with $70 \%$ alcohol and evaporated until extract is obtained, b. A sampling of skipjack fish from the Fish Auction Place (TPI). Then brought to the laboratory to be cleaned, then immersed the extract for 10 minutes. After that, fumigation was carried out and taken to the Gorontalo University microbiology laboratory for further packaging. then under the Hasanuddin university nutrition and animal feed laboratory for proximate analysis, c. Experimental design This study used a completely randomized design with treatment using 10\% starfruit leaf extract and without treatment with 3 replications, $d$. The data obtained in this study were arranged qualitatively and quantitatively. Then analyzed using a one-way ANOVA analysis.

\section{RESULTS}

\section{A. Water Content in Skipjack Smokefish}

Water content is one of the important elements in food, although it is not a nutrient source its existence is very essential in the continuation of the biochemical processes of living organisms. Free water can help the process of damage to food, such as microbiological, chemical, enzymatic processes, even by destructive insect activity. Water content in smoked skipjack can be seen in Figure 1. 


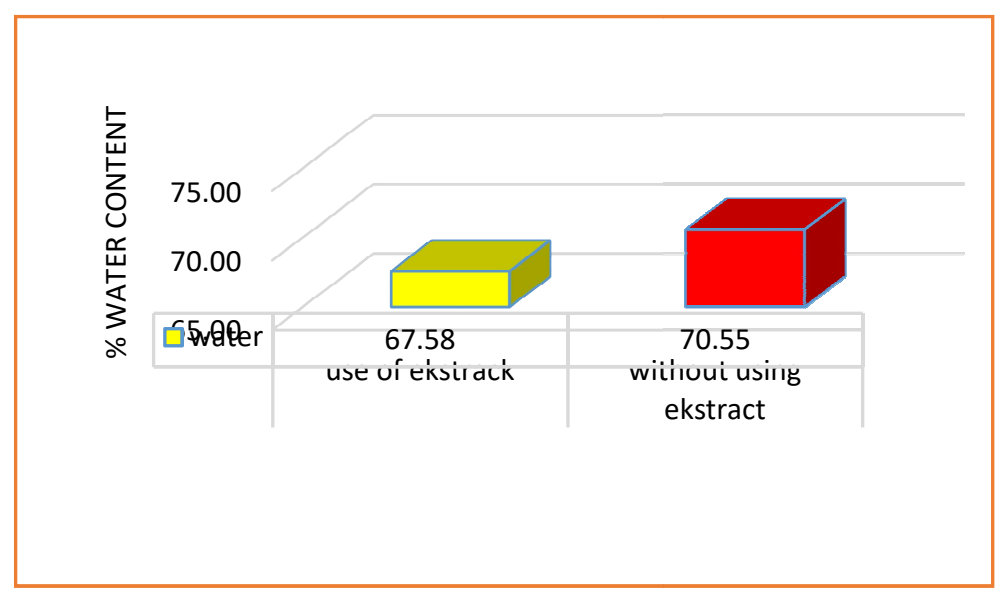

Figure 1. Water Content in Skipjack Smoke Fish.

Based on figure 1, the results of this study show that the water content in smoked skipjack which is treated with extract of starfruit leaves has decreased. It is predicted that the temperature and duration of fuming affect the water content of the food. This is because the water content in food evaporates from a liquid state and then becomes gas and is absorbed by the air contained in the smoke cabinet. The amount of water vapor absorbed by air depends on the length and temperature used in the fumigation process. [5] states that the longer the smoke is, the lower the water content will be, as is the case with the temperature used, the higher the temperature used, the lower the water content. According to [6], the old fumigation process causes a decrease in water contentingredients form smoke on the surface of the fish, and high temperatures in the fumigation process cause antibacterial.

Based on the results of the T-test, the extract of starfruit leaf extract had a significant effect $\mathrm{t}<\mathrm{T} 0.05$ on the moisture content of the food. Also, the method of fumigation also greatly affects the low water content. In this study, fumigation was carried out using a hanging method, so that the water contained in foodstuffs was reduced.

\section{B. Protein Content In Skipjack Smoke Fish}

Protein is a food substance in the form of amino acids which functions as a builder and regulator for the body. Protein contains elements of carbon, hydrogen, oxygen, and nitrogen which fat or carbohydrates do not have. Protein molecules also contain phosphorus, sulfur and some proteins have metal elements such as iron and copper [7]. The research results can be seen in Figure 2. 


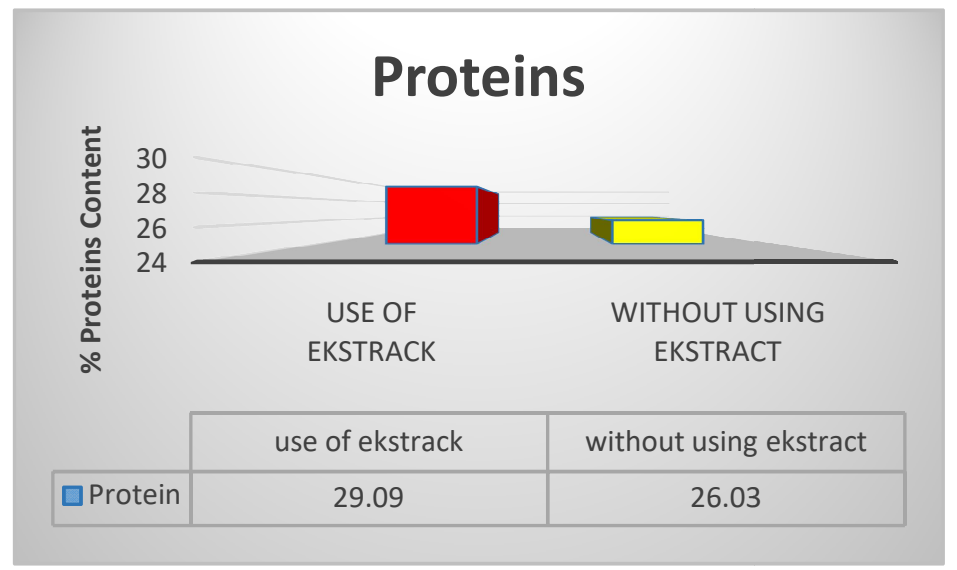

Figure 2.Protein Content in Skipjack Smoke Fish

The high levels of protein in Figure 2 are thought to be due to the low water content found in extracted samples. Water is the best medium for the growth of microorganisms such as bacteria. Bacteria can remodel the amino acids contained in fish so that there will be a protein decarboxylation. According to [8], the high and low measured protein values can be influenced by the amount of water dehydrated from the material. [9], states that microbial activity during storage results in decomposition of chemical compounds of meat, especially proteins that will be broken down into simpler compounds. This is supported by the opinion [10], stating that there is a change in the binding capacity of post-mortem muscle tissue. Changes in the water-binding capacity are related to the ability of muscle proteins to bind water, while the ability of muscle proteins is influenced by the $\mathrm{pH}$ value and the amount of ATP muscle tissue.

Welch starfruit leaves have antibacterial activity because they contain tannins, flavonoids, and saponins. Antibacterials can be used as natural preservatives, which can inhibit food damage due to microbial activity. Sing et.al 1991, said that tannins can bind proteins to form complex protein bonds so proteins are difficult to digest by protease enzymes that will produce amino acids needed by the body. Tanin is also an anti-nutrient that can bind to proteins. Tannin also influences carbohydrate metabolism by binding to starch, making it difficult to digest by amylase enzymes [11]. This is supported which states that protein-tannin interactions occur during oxidation which leads to degradation of parent compounds and the formation of interaction products. This, in turn, can affect the quality of protein and foods containing tannin. But it does not occur in sample fish. This is presumably because the fish was soaked with the extract intact so that the extract did not absorb completely into the meat. 


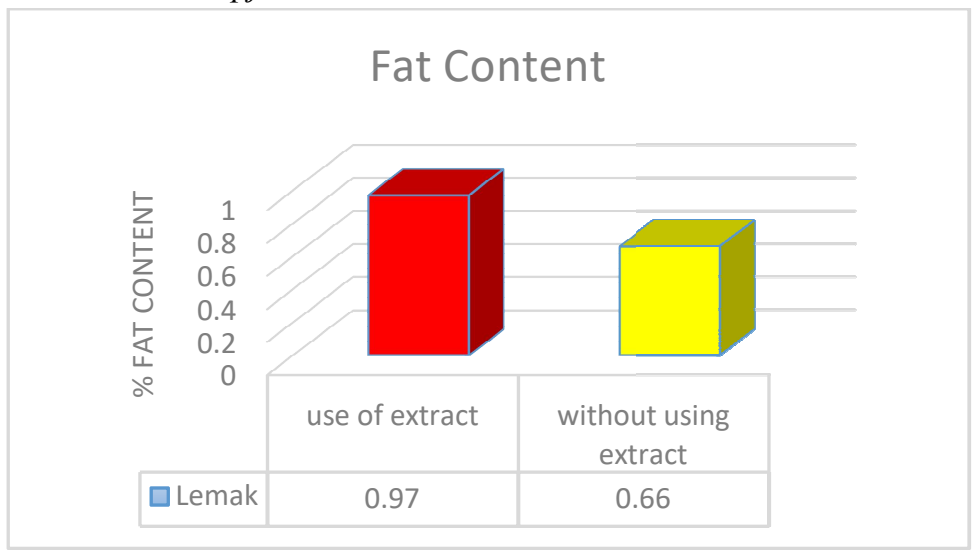

Figure 3.Fat Content in Skipjack Smoke Fish

According to [12], reported that changes in protein content during growth were proportional to changes in fat content in tilapia meat. Increased protein content in the body of the fish fat content will decrease. Fat levels decrease at low temperatures and increase at high temperatures. This is also supported by the opinion of that loss of fat and water levels can occur due to the denaturation of proteins in tissues at levels that can cause a decrease in water binding capacity and emulsification properties of proteins. It can be suspected that the content of phenol compounds that act as antioxidants in the extract of Sargassum sp. will suppress the occurrence of oxidation reactions so that fish fillets with the addition of Sargassum sp. have high-fat content compared to catfish fillets without the addition of Sargassum sp. extract. This is by the opinion of Sanger [13], which states that phenol compounds can inhibit fat oxidation thus preventing fat damage.

Starfruit leaf extract contains flavonoids which have an antioxidant ability that can transfer an electron to free radical compounds and form complexes with metals. Both mechanisms make flavonoids have several effects, including inhibiting lipid peroxidation, suppressing tissue damage by free radicals and inhibiting some enzymes [14]. 


\section{CONCLUSION}

Based on the results of the study it can be concluded that the use of natural preservatives, in this case, the extract of the starfruit leaves does not significantly affect the fat and protein levels, but significantly affects the water content. This means that Wuluhstarfruit leaf extract can be used as a natural preservative because it does not affect the nutritional content of the food.

\section{REFERENCES}

[1] Bei Wang, Marina Heinonen, 2016. Protein-Tannin Interactions of Tryptic Digests of $\alpha$-Lactalbumin and Procyanidins J. Agric. Food Chem.2017. 651148-155 Publication Date:December 7, 2016. https://doi.org/10.1021/acs.jafc.6b04256

[2] DKP

ProvinsiGorontalo., 2011.

[3] DKP

ProvinsiGorontalo., 2015

[4] Rais, I. R., 2015. Isolasi dan penentuankadar flavonoid ekstra ketan olikher basambiloto (andro graphi spaniculata (burm. F.) Ness). Pharmaciana, pp 100:106

[5] Sulfiani,Andi Sukainah,AmirahMustarin, 2017. Pengaruh lama dan suhu pengasapan dengan menggunakan metode pengasapan panas terhadap mutu ikan lele asap. Jurnal PendidikanTeknologi Pertanian, Vol. 3 (2017) : S93-S101

[6] Marassebesy Ismael danRoyani DS. 2011. Perbaikan Teknologi Pengasapan dan Manajemen. Usaha Pengolahan IkanAsap. Jurnal Bakti.

[7] Pratama, R. I., I. Rostini, dan E. Liviawaty. 2014. Karakteristik Biskuit dengan Penambahan Tepung Tulang Ikan Jangilus

[8] Budianto A K. 2009. Pangan, Gizi, dan Pembangunan Manusia Indonesia: Dasar- Dasar Ilmu Gizi. Malang: UMM

[9] Jaelani, A., S. Dharmawati dan Wanda. 2014. Berbagai Lama Penyimpanan Daging Ayam Broiler Segar dalam Kemasan Plastik pada Lemari Es (Suhu $4^{\circ} \mathrm{C}$ ) dan Pengaruhnya Terhadap Sifat Fisik dan Organoleptik. Ziraa'ah. 39 (3): 119-128. ISSN Elektronik 2355- 3545.

[10] Soeparno . 2004. IlmudanTeknologiDaging. GadjahMada University Press Yogyakarta.

[11] Tandi, J.E. 2010. Pengaruh Tannin terhadapaktifitasEnzim Protease. Fakultas Peternakan Unhas. Seminar Nasional Teknologi Peternakan danVeteriner.

[12] M. Isa, Rinidar, Tia ZaliaBtb, Abdul Harris, Sugito, danHerrialfian. 2015 Proximate Analysis of Fat Content on Tilapia Fish Suplemented with Willow Leaf Combinated with Chromium in Feed after Exposured 
of Heat Stress.Jurnal MedikaVeterinaria Vol. 9 No. 1, Februari 2015 ISSN : 0853-1943

[13] Sanger, G. 2010. Oksidasi Lemak IkanTongkol (Auxisthazard) Asap yang Direndam dalam Larutan Ekstrak DaunSirih. Pacific Journal. 2 (5): 870-873. ISSN 1907.9672

[14] Harborne, J.B. 1987. Metode Fitokimi Penuntun Cara Modern Menganalisis Tumbuhan. Penerbit ITB. Bandung. 